\title{
Diagnosis of Helicobacter pylori infection in patients with bleeding ulcer disease: rapid urease test and histology
}

\author{
M. Castro-Fernández, D. Sánchez-Muñoz, E. García-Díaz, J. Miralles-Sanchiz¹ and J. Vargas-Romero² \\ Services of Digestive Diseases, 'Pathology and ${ }^{2}$ Microbiology. Valme University Hospital. Seville. Spain.
}

\begin{abstract}
Introduction: the endoscopic diagnosis of Helicobacter pylo$r i$ infection in patients with bleeding peptic ulcer is limited by a decreased sensitivity in standard invasive tests, rapid urease test and histology. There is controversy about the convenience of using one, neither, or both diagnostic tests.

Aims: to evaluate the results of simultaneously performed rapid urease test and histology in the diagnosis of Helicobacter pylori infection $(H$. pylori) in patients with bleeding peptic ulcer.

Patients and methods: we included 173 patients, 98 male and 75 female, with an average age of 62 years (18-88), with upper gastrointestinal bleeding secondary to duodenal ulcer (115) or gastric ulcer (58), diagnosed within 24 hours after hospital admission. None of the patients had received treatment for $H$. pylori, proton pump inhibitors or antibiotics in the two weeks prior to the upper gastrointestinal bleeding episode. H. pylori infection was investigated in all patients by two antral biopsy samples for histological study (hematoxilin-eosin) and one or two antral biopsies for rapid urease test (Jatrox ${ }^{\circledR}-H$.p.-test). In cases with a negative urease test and histology, a ${ }^{13} \mathrm{C}$ urea breath test was performed. Infection was considered present when at least one invasive test or the breath test was positive, whereas both invasive tests and the breath test had to be negative to establish an absent infection.

Results: 152 patients (88\%) showed $H$. pylori infection, 104 patients (90\%) with duodenal ulcer and 48 patients (83\%) with gastric ulcer. In all 119 cases (78\%) were diagnosed by the urease test and 112 cases (74\%) by histology. Both methods were used to diagnose 134 of 152 cases $(88 \%)(p<0.05)$, these being positive in 97 cases and negative in 39 cases. In 18 of these 39 cases, the breath test was positive.

Conclusions: histology and urease test have similar diagnostic values for the identification of $H$. pylori in patients with bleeding peptic ulcer. Due to its rapid results, the urease test should be the method of choice. However, additional biopsies should be performed, and, when negative, a histological study should be carried out, since a combination of both methods allows a more precise diagnosis.
\end{abstract}

Key words: Helicobacter pylori. Urease test. Histology. Diagnosis of $H$. pylori. Upper gastrointestinal bleeding.

Recibido: 15-09-03.

Aceptado: 23-12-03.

Correspondencia: Manuel Castro Fernández. Servicio de Aparato Digestivo ( $9^{a}$ planta). Hospital Universitario de Valme. Carretera de Cádiz, s/n. 41014 Sevilla. e-mail: mcastrof@meditex.es
Castro-Fernández M, Sánchez-Muñoz D, García-Díaz E, Miralles Sanchiz J and Vargas-Romero J. Diagnosis of Helicobacter pylori infection in patients with bleeding ulcer disease: rapid urease test and histology. Rev Esp Enferm Dig 2003; 96: 395-401.

\section{INTRODUCTION}

Helicobacter pylori (H. pylori) infection is the most frequent cause of peptic ulcer disease. The prevalence of this infection in duodenal and gastric ulcers is $90-95 \%$ and $80-85 \%$, respectively $(1,2)$. Patients with peptic ulcer disease can develop severe complications, such as bleeding or perforation. Thus, it is necessary to reach a precise diagnosis of $H$. pylori infection, as its eradication reduces ulcer recurrence and complications considerably (3-5). Today, there are several diagnostic methods available to detect $H$. pylori infection. These include invasive methods, which require endoscopy and gastric biopsies (rapid urease test, histology, and culture) and non-invasive methods (breath test with ${ }^{13} \mathrm{C}$-labelled urea, stool antigen test, and serology). They all have advantages and disadvantages in terms of availability, rapidity of results, costs, diagnostic precision, etc. (6-9). Invasive methods, especially the rapid urease test, are found to have low diagnostic sensitivity in patients with bleeding peptic ulcer. It has been suggested that the way to proceed in these cases is either to obtain biopsies only for histology or to use a non-invasive diagnostic method $(6,7,10-14)$. The causes for decreased diagnostic sensitivity of invasive methods in cases with upper gastrointestinal bleeding are still unclear, and which diagnostic method should be used in these cases has not been established either.

The aim of this study was to analyze the diagnostic value of rapid urease tests and histology in patients with bleeding peptic ulcer. 


\section{PATIENTS AND METHODS}

\section{Patients}

We included 173 patients, 98 male and 75 female, aged 62 (18-88) years on average, with upper gastrointestinal bleeding secondary to duodenal ulcer (115 cases) or gastric ulcer (58 cases), as diagnosed by an endoscopy performed within the first twenty-four hours after hospital admission. None of the patients showed either active bleeding or red blood in the stomach or duodenum. All patients had received intravenous omeprazole (40-160 $\mathrm{mg}$ ) for less than 24 hours before endoscopy. Patients had not received treatment for $H$. pylori, proton pump inhibitors (PPI), or antibiotics in the two weeks prior to the upper gastrointestinal bleeding.

\section{Diagnostic methods}

H. pylori infection was investigated in all patients by antral biopsy samples, two of these for histological study (hematoxilin-eosin), and one or two for rapid urease test (Jatrox ${ }^{\circledR}$-H.p.-Test). In cases with gastric ulcer, biopsies were taken from the lesion to confirm its benign etiology. The rapid urease test was considered to be positive when a color change (from yellow to red) occurred within 24 hours after introducing the sample into a cuvette containing the reactive and $0.5 \mathrm{ml}$ of distilled water. The histological study was performed without previous knowledge of the rapid urease test results. The histological diagnosis was considered to be positive when bacterial forms morphologically compatible with $H$. pylori were detected on the glycocalix of the surface epithelium, together with the standard secondary inflammatory changes.

In cases with negative results for these two invasive methods, a ${ }^{13} \mathrm{C}$ urea breath test was performed (TAUKITIsomed Farmacéutica. Madrid) 6 to 8 weeks after endoscopy, following a minimum of 2 weeks without PPI consumption according to the manufacturer's instructions. Samples were analyzed using a mass spectrophotometer. Tests were considered positive when the increased value of ${ }^{13} \mathrm{C}$ (the difference between a baseline sample and another one taken after 30 minutes) was greater than 5 delta units $(>5 \%$ ).

\section{Criteria for $\boldsymbol{H}$. pylori infection}

Patients were considered to have $H$. pylori infection when there were positive results in, at least, one of the two invasive tests performed -rapid urease test, histological examination with hematoxilin-eosin- or in the ${ }^{13} \mathrm{C}$ urea breath test. $H$. pylori infection was excluded when both invasive tests and ${ }^{13} \mathrm{C}$ urea breath test were negative.

\section{Statistical study}

Data were studied by means of an analysis of the statistical significance of percentage differences found when comparing the results of the different diagnostic methods evaluated, applying the Chi square, Fisher's exact, and McNemar tests. We considered the results to be statistically significant when $\mathrm{p}<0.05$. Confidence intervals were calculated at $95 \%$.

\section{RESULTS}

In all, 152 of 173 patients $(88 \%)$ showed $H$. pylori infection criteria, $104(90 \%)$ with duodenal ulcer, and 48 $(83 \%)$ with gastric ulcer. The results obtained with the different diagnostic methods are detailed in table I.

The rapid urease test was positive in 119 of 152 cases with infection criteria (78\%); histology was positive in 112 cases $(74 \%)$, and differences showed no statistical significance.

In addition, 134 of 152 cases (88\%) were accurately diagnosed by associating the results of the two invasive diagnostic methods. We found statistically significant differences $(p<0.05)$ when comparing this result with those of the two diagnostic techniques, separately.

\section{DISCUSSION}

The prevalence of $H$. pylori infection in populations with gastro-duodenal ulcer is very high. In gastric and duodenal ulcers, prevalence of $60-100 \%$ and $90-100 \%$, respectively, have been reported $(1,2)$. These were slightly lower or similar in bleeding ulcer disease studies when patients taking

Table I. Results of the urease test, histology, and breath test for the diagnosis of Helicobacter pylori infection in patients with bleeding from either gastric ulcer or duodenal ulcer

\begin{tabular}{lccccc}
\hline Urease test & Histology & $\begin{array}{c}\text { Breath test with } \\
{ }^{13} \text { C urea }\end{array}$ & $\begin{array}{c}\text { Duodenal ulcer } \\
(n=115)\end{array}$ & $\begin{array}{c}\text { Gastric ulcer } \\
(n=58)\end{array}$ & $\begin{array}{c}\text { Overall Group } \\
(n=173)\end{array}$ \\
\hline Positive & Positive & - & $72(62.6 \%)$ & $25(43.1 \%)$ & $97(56.0 \%)$ \\
Positive & Negative & - & $13(11.3 \%)$ & $9(15.5 \%)$ & $22(12.7 \%)$ \\
Negative & Positive & - & $8(6.9 \%)$ & $7(12.0 \%)$ & $15(8.6 \%)$ \\
Negative & Negative & Positive & $11(9.5 \%)$ & $7(12.0 \%)$ & $18(10.4 \%)$ \\
Negative & Negative & Negative & $11(9.5 \%)$ & $10(17.2 \%)$ & $21(12.1 \%)$ \\
\hline
\end{tabular}


non-steroidal anti-inflammatory drugs (NSAIDs) were excluded (15). In our study there was a 90.4 and $82.7 \%$ prevalence of infection in patients with duodenal ulcer and gastric ulcer, respectively. Despite this high prevalence, it is not advisable to assume that all patients with gastro-duodenal ulcer, even when they are not taking NSAIDs, are infected by $H$. pylori. Due to its simplicity, precision and rapid results, the rapid urease test is considered the invasive method of choice in patients requiring endoscopy $(16,17)$, even despite the fact that, as is the case with other invasive methods, it exhibits a lower diagnostic sensitivity in cases of bleeding ulcer disease $(6,11,13,18,19)$. Our group considered this problem in a previous report, in which patients with non-complicated gastroduodenal ulcer and patients with upper gastroduodenal bleeding were included (20). In these instances it has been recommended that only histology-rather than the urease test-should be performed as loss of sensitivity will be lower (21-23). The other alternative is to perform a non-invasive-rather than an invasive-test (i. e. a ${ }^{13} \mathrm{C}$ urea breath test or stool antigen test) after upper gastrointestinal bleeding has ceased $(7,10)$. Serology is not advisable (24). As for histology, the various factors which affect the accurate identification of bacteria include: type of dye used, experience of the observer, amount and quality of sample referred for examination, existence of previous treatments, density of bacterial colonies, and presence of extensive intestinal metaplasia. The causes for decreased diagnostic sensitivity of the urease test in bleeding gastroduodenal ulcer are still controversial. Potential causes suggested for this lower sensitivity include the presence of blood in the stomach, which could lead to a transient clearance of bacterial density as a result either of a bactericide effect of serum $(7,25)$, or bacteria proximal migration in the stomach due to intragastric $\mathrm{pH}$ changes, leading to a decrease in antral bacterial density; the possibility that albumin in blood serum may act as buffer on the $\mathrm{pH}$ indicator used in the urease test, which could prevent color change (26); or that frequent use of PPI in these patients may result in a reduction of bacterial load in the mucosa $(6,27)$. Some of these factors could also be involved in the decreased sensitivity of histological studies. Nevertheless, the presence of both urease test and histology false negative results may share a common mechanism; our patients were under the effects of intravenous omeprazole, although for a short period of time, at the time of endoscopy, but they were not exposed to the presence of gastroduodenal blood, however.

In our study we found that no method is better than the rest in terms of their capability to detect $H$. pylori $(78 \mathrm{vs}$ $74 \%$ ). However, as we expected, when both methods (urease test and histology) are simultaneously used, diagnostic value increases (88 vs 74-78\%; $\mathrm{p}<0.05$ ).

Due to its simplicity and rapidity of results, the rapid urease test is, in our opinion, the invasive method of choice. However, although this test shows a high false negative results rate when upper gastrointestinal bleeding occurs, additional biopsies should be obtained for a histological study, thus improving diagnostic yield (28). The possibility of an increase in sensitivity for both diagnostic methods when simultaneous antral and fundic biopsy samples are taken is likely. A positive result in either of these methods would be sufficient to reach a diagnosis, but when they are both negative-even considering the limitations in diagnostic sensitivity invasive methods exhibit when hemorrhagic complications are there-infection should be ruled out by using other non-invasive methods (breath test or stool antigen test) once the acute phase of the hemorrhagic process has been overcome.

Despite all this, further studies are still mandatory both to determine which diagnostic method is the most reliable for detecting $H$. pylori in patients with bleeding peptic ulcer, and to establish the appropriate timing in studying these patients' infections.

\section{REFERENCES}

1. Kuipers EJ, Thijs JC, Festen HP. The prevalence of Helicobacter pylori in peptic ulcer disease. Aliment Pharmacol Ther 1995; 9 (Suppl. 2): 59-69.

2. Gisbert JP, Boixeda D, Aller R, de la Serna C, Sanz E, Martín de Argila $\mathrm{C}$, et al. Helicobacter pylori and digestive hemorrhage due to duodenal ulcer: the prevalence of the infection, the efficacy of 3 triple therapies and the role or eradication in preventing a hemorrhagic recurrence. Med Clin (Barc.) 1999; 112: 161-5.

3. Barhel JS. Bleeding ulcers and Helicobacter pylori. Gastrointest Endosc 1997; 46: 371-3.

4. Santander C, Gravalos RG, Gómez-Cedenilla A, Canter J, Pajares JM. Antimicrobial therapy for helicobacter pylori infection versus long-term maintenance antisecretion treatment in the prevention of recurrent hemorrhage from peptic ulcer: prospective randomized trial on 125 patients. Am J Gastroenterol 1996; 91: 1549-52.

5. Riemann JF, Schilling D, Schauwecker P, Wehlen G, Dorlars D, Kohler B. Cure with omeprazole plus amoxicillin versus long-term ranitidine therapy in Helicobacter pylori associated peptic ulcer bleeding. Gastrointest Endosc 1997; 46: 299-304.

6. Gisbert JP. A critical review of the diagnostic methods for Helicobacter pylori infection. Gastroenterol Hepatol 2000; 23: 135-43.

7. Martín de Argila C, Boixeda D. Practical considerations for the diagnosis of Helicobacter pylori infection. Med Clin (Barc) 2001; 117: 386-91.

8. Megraud F. Advantages and disadvantages of current diagnostic test for the detection of Helicobacter pylori. Scand J Gastroenterol 1996; 31 (Suppl. 215): 57-62.

9. De Boer WA, De Laat L, Megraud F. Diagnosis of Helicobacter pylori infection. Current Opinión in Gastroenterology 2000; 16 (Suppl. 1): S5-S10.

10. Sainz R, Borda F, Domínguez E, Gisbert JP. Grupo Conferencia Española de Consenso. Conferencia Española de Consenso sobre la infección por Helicobacter pylori. Rev Esp Enferm Digest 1999; 91: 777-84.

11. Colin R, Czernichow P, Baty V, Tozue I, Brazier F, Bretagne JF, et al. Low sensitivity of invasive tests for the detection of Helicobacter pylori infection in patients with bleeding ulcer. Gastroenterol Clin Biol 2000; 24: 31-5.

12. Howden CW, Hunt RH. Guidelines for the management of Helicobacter pylori infection. Am J Gastroenterol 1998; 93: 2330-8.

13. Tu T-C, Lee C-L. Wu C-H, Chen T-K, Chan C-C, Huang S-H, et al. Comparison of invasive and noninvasive tests for detecting Helicobacter pylori infection in bleeding peptic ulcers. Gastrointest Endosc 1999; 49: 302-6.

14. Lee JM, Breslin NP, Fallon C, O’Morain CA. Rapid urease test lack sensitivity in Helicobacter pylori diagnosis when peptic ulcer disease presents with bleeding. Am J Gastroenterol 2000; 95: 1166-70.

15. Gisbert JP, González L, de Pedro A, Valvuena M, Prieto B, Llorca I, et al. Helicobacter pylori and bleeding duodenal ulcer: prevalence of the infection and role of non-steroidal anti-inflammatoy drugs. Scand J Gastroenterol 2001; 36: 717-24.

16. Laine L, Cohen H. Helicobacter pylori: drowning in a pool of blood? Gastrointest Endosc 1999; 49: 398-402. 
17. Lam SK, Talley NJ. Helicobacter pylori. Consensus Report of the 1997 Asia Pacific Consensus Conference on the management. J Gastroenterol Hepatol 1998; 13: 1-12.

18. Grino P, Pascual S, Such J, Casellas JA, Niveiro M, Andreu M et al. Comparison of diagnostic methods for Helicobacter pylori infection in patients with upper gastrointestinal bleeding. Scand J Gastroenterol 2001; 36: 1254-8.

19. Chung IK, Hong SJ, Kim EJ, Cho JY, Kim HS, Park SH et al. What is the best method to diagnose Helicobacter infection in bleeding peptic ulcers? A prospective trial. Korean J Intern Med 2001; 16: 147-52.

20. Romero-Gómez M, Vargas J, Utrilla D, Rufo MC, Otero MA, Chavez $\mathrm{M}$ et al. Estudio prospectivo sobre la influencia de la hemorragia por ulcus gastroduodenal en los métodos diagnósticos de infección por Helicobacter pylori. Gastroenterol Hepatol 1998; 21: 267-71.

21. Castillo-Rojas G, Ballesteros MA, Ponce de León S, Morales-Espinosa R, Cravioto A, López-Vidal I. Bleeding peptic ulcers and presence of Helicobacter pylori by various tests: a case-control study. Eur J Gastroenterol Hepatol 2002; 14: 1113-8.

22. Archimandritis A, Tzivras M, Sougioultzis S, Papaparaskevas I, Apostolopoulos P, Aviami A et al. Rapid urease test is less sensitive than histology in diagnosing Helicobacter pylori infection in patients with non-variceal upper gastrointestinal bleeding. J gastroenterol Hepatol 2000; 15: 369-73.
23. Calvet X,Gisbert JP. Prevención de la recidiva hemorrágica por úlcera péptica en pacientes infectados por Helicobacter pylori. GH Continuada 2002; 1: 48-51.

24. García-Díaz E, Castro-Fernández M, Romero-Gómez M, Vargas-Romero J. The effectiveness of (IgG-ELISA) serology as an alternative diagnostic method for detecting Helicobacter pylori infection in patients with gastro-intestinal bleeding due to gastro-duodenal ulcer. Rev Esp Enferm Dig 2002; 94: 731-6.

25. Houghton J, Ramamoorthy R, Pandya H, Dhirmalani R, Kim KD. Human plasma is directly bacteriocidal against Helicobacter pylori in vitro, potentially explaining the decreased detection of Helicobacter pylori during acute upper gastrointestinal bleeding. Gastrointest Endosc 2002; 55: 11-16.

26. Leung WK, Sung JJ, Siu KL, Chan FK, Ling TK, Cheng AF. Falsenegative biopsy urease test in bleeding ulcers caused by the buffering effects of blood. Am J Gastroenterol 1999; 94: 1421-2.

27. Graham DY, Opekun AR, Hammond F, Yamaoka Y, Reddy R, Osato El-Zimaity HM. Studies regarding the mechanism of false negative urea breath test with proton pump inhibitors. Am J Gastroenterol 2003; 98: 1005-9.

28. Schilling D, Demel A, Adamek HE, Nusse T, Weidmann E, Riemann JF. A negative rapid urease test is unrliable for exclusion of Helicobacter pylori infection during acute phase of ulcer bleding. A prospective case control study. Dig Liver Dis 2003; 35: 215-6.

\title{
Diagnóstico mediante endoscopia de la infección por Helicobacter pylori en pacientes con úlcera gastroduodenal y hemorragia digestiva: test rápido de ureasa e histología
}

\author{
M. Castro-Fernández, D. Sánchez-Muñoz, E. García-Díaz, J. Miralles-Sanchiz y y J. Vargas-Romero² \\ Servicios de Aparato Digestivo, 'Patología y ${ }^{2}$ Microbiología. Hospital Universitario de Valme. Sevilla
}

\section{RESUMEN}

Introducción: el diagnóstico de la infección por Helicobacter pylori, mediante endoscopia, en pacientes con úlcera gastroduodenal y hemorragia digestiva está limitado por la disminución de la sensibilidad de los métodos invasivos habituales, test de la ureasa e histología. Existen controversias sobre el valor diagnóstico de practicar, en estos pacientes, alguna, ninguna o ambas pruebas diagnósticas.

Objetivos: valorar los resultados del test rápido de ureasa y la histología, practicados simultáneamente, en el diagnóstico de infección por Helicobacter pylori (H. pylori) en pacientes con úlcera gastroduodenal y hemorragia digestiva.

Pacientes y métodos: incluimos 173 pacientes, 98 varones y 75 mujeres, edad media de 62 años (18-88), con hemorragia digestiva por úlcera duodenal (115) o gástrica (58), diagnosticados por endoscopia en las primeras 24 horas del ingreso. Ningún paciente había recibido tratamiento erradicador frente a $H$. pylori ni consumido inhibidores de la bomba de protones o antibióticos en al menos las dos semanas previas al ingreso. Investigamos la presencia de $H$. pylori mediante la obtención de dos biopsias antrales, para estudio histológico (hematoxilina-eosina) y una o dos biopsias, también antrales, para el test rápido de ureasa. En los casos con test de ureasa e histología negativos se practicó test del aliento con urea marcada con ${ }^{13} \mathrm{C}$. Consideramos presencia de infección cuando al menos una de las pruebas invasivas o el test del aliento eran positivos y ausencia de infección cuando las dos pruebas invasivas y el test del aliento eran negativos.

Resultados: ciento cincuenta y dos pacientes (88\%) presentaban infección por $H$. pylori, 104 (90\%) en el grupo con úlcera duodenal y 48 (83\%) en el grupo con úlcera gástrica. El test de ureasa resultó positivo en 119 casos (78\%) y la histología en 112 casos (74\%). Con ambos métodos diagnosticamos 134 de los 152 casos $(88 \%)(p<0,05)$. Ambos métodos fueron positivos en 97 casos y negativos en 39 casos. En 18 de estos 39 casos el test del aliento resultó positivo.

Conclusiones: la histología y el test de ureasa tienen un valor diagnóstico similar en la detección de $H$. pylori en pacientes con 
úlcera gastroduodenal y hemorragia digestiva. El test de la ureasa, por la rapidez del resultado, debe ser el método de elección, pero puede ser conveniente obtener biopsias adicionales $y$, ante un resultado negativo, realizar estudio histológico, obteniéndose con ambos métodos una mayor precisión diagnóstica.

La negatividad del test de la ureasa y/o de la histología no descarta la infección por $H$. pylori.

Palabras clave: Helicobacter pylori. Test de ureasa. Histología. Diagnóstico de H. pylori. Hemorragia digestiva alta.

\section{INTRODUCCIÓN}

La infección por Helicobacter pylori (H. pylori) es la causa más frecuente de la enfermedad ulcerosa gastroduodenal. La prevalencia de esta infección en las úlceras duodenales y gástricas es del 90-95 y 80-85\% respectivamente $(1,2)$. Los pacientes con enfermedad ulcerosa gastroduodenal pueden desarrollar complicaciones graves, como hemorragia digestiva o perforación, siendo necesario realizar un diagnóstico preciso de la infección por $H$. pylori, ya que su erradicación reduce considerablemente las recidivas ulcerosas y sus complicaciones (3-5). Disponemos de diversos métodos diagnósticos de infección por $H$. pylori, ya sean invasivos, que precisan la práctica de gastroscopia y biopsias gástricas (test rápido de la ureasa, histología y cultivo) o no invasivos (test del aliento con urea ${ }^{13} \mathrm{C}$, detección de antígenos en heces y serología), que presentan ventajas e inconvenientes, en relación a disponibilidad, rapidez en resultados, coste o exactitud diagnóstica, etc. (6-9). Los métodos invasivos, especialmente el test de la ureasa, muestra una baja sensibilidad diagnóstica en los casos de úlcera gastroduodenal con hemorragia digestiva y, en estos casos, se ha sugerido la obtención de biopsias únicamente para histología o realizar un método diagnóstico no invasivo $(6,7,10-14)$. No están aclaradas las causas que motivan el descenso de la sensibilidad diagnóstica de los métodos invasivos en los casos de hemorragia digestiva, y tampoco está totalmente definido qué método diagnóstico debemos emplear en estos casos.

El objetivo de este estudio es analizar el valor diagnóstico del test rápido de la ureasa y de la histología en pacientes con úlcera gastroduodenal y hemorragia digestiva.

\section{PACIENTES Y MÉTODOS}

\section{Pacientes}

Se incluyen 173 pacientes, 98 varores y 75 mujeres, con edad media de 62 (18-88) años con hemorragia digestiva por úlcera duodenal (115 casos) o gástrica (58 casos), diagnosticados por gastroscopia realizada en las primeras 24 horas del ingreso. Ningún paciente presentaba hemorragia activa o restos hemáticos rojizos en estómago o duodeno. Todos los pacientes habían iniciado trata- miento con omeprazol intravenoso, con dosis variables (40-160 mg) y durante un periodo inferior a 24 horas. Ningún paciente había recibido tratamiento erradicador para $H$. pylori ni referían consumo de inhibidores de la bomba de protones (IBP) o antibióticos en al menos las dos semanas previas al ingreso hospitalario.

\section{Métodos diagnósticos}

En todos los pacientes se investigó la infección por $H$. pylori mediante la obtención de biopsias antrales, dos para estudio histológico (tinción con hematoxilina-eosina) y una o dos para realizar el test rápido de la ureasa (Jatrox ${ }^{\circledR}$-H.p.-Test). En los casos con úlcera gástrica se tomaron biopsias de la lesión para confirmar su naturaleza benigna. El test rápido de la ureasa se consideró positivo cuando se producía el viraje de color (de amarillo a rojo) en las primeras 24 horas, tras introducir la muestra en un pocillo con el reactivo y $0,5 \mathrm{ml}$ de agua destilada. El estudio histológico se realizó sin conocimiento del resultado del test rápido de la ureasa. Se consideró un diagnóstico histológico positivo cuando se observaron formas bacterianas morfológicamente compatibles con $H$. pylori en el glicocálix del epitelio de superficie, junto a las alteraciones inflamatorias propias secundarias.

No se consideró la posibilidad de falsos positivos del test de ureasa ni de la histología.

En los casos con negatividad a los dos métodos invasivos se realizó un test de aliento con urea ${ }^{13} \mathrm{C}$, (TAUKIT- Isomed Farmacéutica. Madrid), a las 6-8 semanas de la hemorragia digestiva, tras un mínimo de 2 semanas sin consumo de IBP, y de acuerdo con las instrucciones del fabricante. Las muestras se analizaron mediante un espectrofotómetro de masas y se consideraron positivas cuando el valor incremental de ${ }^{13} \mathrm{C}$ (diferencia entre muestra basal y a los $30 \mathrm{mi}$ nutos) era superior a 5 unidades delta $(>5 \%$ ).

\section{Criterios de infección por $H$. pylori}

Se consideró que el paciente presentaba infección $H$. pylori cuando existía positividad en al menos uno de los dos métodos invasivos practicados (test rápido de la ureasa o estudio histológico con hematoxilina-eosina), o al test del aliento.

Se consideró que el paciente no presentaba infección H. pylori cuando los dos métodos invasivos y el test del aliento eran negativos.

\section{Estudio estadístico}

Los datos se estudiaron analizando la significación estadística de las diferencias porcentuales obtenidas al comparar los resultados de los distintos métodos diagnósticos que se evaluaron, aplicando las pruebas del Chi cua- 
drado, exacto de Fisher y test de McNemar. Consideramos los resultados como estadísticamente significativos cuando obteníamos una $\mathrm{p}<0,05$. Se calcularon los intervalos de confianza al $95 \%$.

\section{RESULTADOS}

Ciento cincuenta y dos de los 173 pacientes $(88 \%)$ tenían criterios de infección por $H$. pylori, 104 (90\%) con úlcera duodenal y 48 (83\%) con úlcera gástrica.

Los resultados obtenidos con los distintos métodos diagnósticos se detallan en la tabla I .

El test rápido de la ureasa fue positivo en 119 de los 152 casos con criterios de infección (78\%), y la histología en 112 casos $(74 \%)$, con diferencias sin significación estadística. Ciento treinta y cuatro de los 152 casos (88\%) se diagnosticaron correctamente al asociar el resultado de los dos métodos diagnósticos. Existían diferencias estadísticamente significativas $(p<0,05)$ al comparar este resultado con el obtenido con los dos métodos diagnósticos de forma independiente.

\section{DISCUSIÓN}

La prevalencia de la infección por $H$. pylori en la población con úlcera gastroduodenal es muy elevada. En las úlceras gástricas y duodenales se han comunicado prevalencias del $60-100 \%$ y del $90-100 \%$ respectivamente $(1,2)$, siendo similares en la enfermedad ulcerosa no complicada o con hemorragia digestiva, especialmente si se excluye la población consumidora de antiinflamatorios no esteroideos (AINE) (15). En nuestro estudio las prevalencias de la infección en la úlcera duodenal y gástrica resultaron del 90,4 y 82,7\% respectivamente. Esta alta prevalencia no justifica que, en la práctica clínica, no realicemos las investigaciones pertinentes y asumamos que todos los pacientes con enfermedad ulcerosa gastroduodenal, no consumidores de AINE, están infectados por H. pylori. El test rápido de la ureasa, en pacientes que requieran endoscopia, se considera el método invasivo de elección por su sencillez, precisión y rapidez del resultado $(16,17)$, aunque presenta una disminución de la sensibilidad diagnóstica en los casos de úlcera gastroduodenal con hemorragia digestiva, como otros métodos invasivos $(6,11,13,18,19)$. Nuestro grupo había constatado esta problemática en un estudio previo, incluyéndose pacientes con úlcera gastroduodenal no complicada y con hemorragia digestiva (20). Algunos autores han recomendado que, en pacientes con úlcera gastroduodenal y hemorragia digestiva, se practique únicamente histología, con aparente menor pérdida de sensibilidad (21-23), en vez del test de la ureasa, o no practicar ningún test invasivo y realizar un test no invasivo (test del aliento o determinación de antígenos en heces) tras superarse la hemorragia digestiva $(7,10)$. No es aconsejable la práctica de serología (24). La histología es un método en el cual influyen diversos factores para la correcta identificación de la bacteria, como el tipo de tinción utilizada, el entusiasmo o experiencia del observador, así como la cantidad y calidad del material remitido para estudio. La causa de la disminución de la sensibilidad diagnóstica del test de ureasa en la úlcera gastroduodenal sangrante sigue siendo motivo de controversia, considerándose diversas circunstancias, como la presencia de sangre en estómago, que podría inducir un aclaramiento transitorio del $H$. pylori por efecto bactericida del suero $(7,25)$, o migración de la bacteria hacia el cuerpo gástrico, por cambios en el pH intragástrico, disminuyendo la densidad bacteriana antral, o bien que la albúmina del suero sanguíneo provoque un efecto tampón sobre el indicador de $\mathrm{pH}$ empleado en el test de ureasa que impediría el viraje de coloración (26). El tratamiento con IBP, habitual en estos pacientes, puede reducir de forma transitoria el número de bacterias en la mucosa gástrica y favorecer su migración hacia cuerpo gástrico, por el incremento del pH intragástrico, originándose resultados falsos negativos de los métodos diagnósticos $(6,27)$. El origen de los falsos negativos del test de la ureasa y de la histología pueden ser similares. Nuestros pacientes estaban expuestos, en el momento de la exploración endoscópica, a los efectos del omeprazol intravenoso, aunque por un periodo inferior a 24 horas, y no, en cambio, a la presencia de sangre reciente en la cavidad gastroduodenal.

En nuestro estudio no observamos que un método sea superior al otro en la capacidad de detección de $H$. pylori (78 vs 74\%), aunque sí existe mayor valor diagnóstico, como cabría esperar, cuando se practican ambos métodos (test de la ureasa e histología) simultáneamente (88 vs 74-78\%; $\mathrm{p}<0,05)$.

Tabla I. Resultados del test de ureasa, de la histología y test del aliento en el diagnóstico de la infección por $H$. pylori en pacientes con hemorragia por úlceras gástricas y duodenales

\begin{tabular}{lccccc}
\hline Test de ureasa & Histología & $\begin{array}{c}\text { Test del aliento } \\
\text { con urea }{ }^{13} \mathrm{C}\end{array}$ & $\begin{array}{c}\text { Pacientes con úlcera } \\
\text { duodenal }(n=115)\end{array}$ & $\begin{array}{c}\text { Paciente con úlcera } \\
\text { gástrica }(n=58)\end{array}$ & $\begin{array}{c}\text { Serie total } \\
(n=173)\end{array}$ \\
\hline Positivo & Positivo & - & $72(62,6 \%)$ & $25(43,1 \%)$ & $97(56,0 \%)$ \\
Positivo & Negativo & - & $13(11,3 \%)$ & $7(12,5 \%)$ & $22(12,7 \%)$ \\
Negativo & Positivo & - & $8(6,9 \%)$ & $7(12,0 \%)$ & $15(8,6 \%)$ \\
Negativo & Negativo & Positivo & $11(9,5 \%)$ & $10(17,2 \%)$ & $18(10,4 \%)$ \\
Negativo & Negativo & Negativo & $11(9,5 \%)$ & & $21(12,1 \%)$ \\
\hline
\end{tabular}


Opinamos que el test de la ureasa, por su sencillez y la rapidez del resultado, es el método invasivo de elección, pero puede ser conveniente obtener biopsias adicionales y, en casos de ser negativo, realizar estudio histológico, con la consiguiente mejora en la capacidad diagnóstica (28). Es probable el incremento de la sensibilidad de ambos métodos diagnósticos con la obtención de biopsias simultáneas de antro y de cuerpo gástrico $(12,14)$. La positividad con alguno de estos métodos sería suficiente para establecer el diagnóstico, pero cuando ambos métodos son negativos, considerando la disminución de la sensibilidad de los métodos invasivos en casos de hemorragia digestiva, se debería investigar la infección con otros métodos, como el test del aliento o determinación de antígeno en heces, una vez superada la fase aguda del proceso hemorrágico y suspendido el tratamiento con IBP.

No obstante, aún se precisan nuevos estudios para determinar que método diagnóstico de infección por $H$. pylori resulta más fiable o es más lógico realizar en pacientes con úlcera gastroduodenal con hemorragia digestiva. 